I82I," ix. + IIo pp. I6mo. In the preface Mollweide says that von Prasse was his predecessor in the Chair of Mathematics, as stated by Prof. Virchl. This work is entered under both the title-names in Poggendorff's "Biographisch-literarisches Handwörterbuch," a circumstance that might have given a clue to the authorship of the "Demonstratio." Strangely enough, this is not the only instance in which von Prasse omitted his name in essays written by him for academical celebrations. I can only surmise that this was done with a view to republication in his "Commentationes Mathematicæ," and that the name was written on the copies distributed as invitations to the celebrations. Whatever the reason, it has in this instance obviously added greatly to the trouble ordinarily experienced when dealing with this class of academical essay, the bibliography of which is so complicated, and at the same time often so important.

Ralph COPELAND.

Lord Crawford's Observatory, Dun Echt, January 25.

\section{A New Historic Comet?}

At a recent meeting of the Asiatic Society of Japan, a paper was read by Mr. W. G. Aston, H.B.M. Consular Service. This paper will certainly rank high amongst historic papers relating to Japan and Korea. Briefly described, it is a comparison between the ancient records of these two countries and China, and its aim is to establish the relative credibility of these various records. Mr. Aston has so far confined his attention to the period precedin A.I. 500 ; and his general conclusion is that, as historic writings, the Korean and Chinese chronicles are far superior to the Japanese of the same date.

In the Tongkan, as the ancient records of the Korean kingdoms are called, there is a notice, of which the following is a translation: "Summer, fourth month, Pèkché ; comet visible; day-time." The fourth month began on May 14 or 15 . At the request of Mr. Aston, I tried to find out if any such comet had been observed elsewhere. The only list of historic comets obtainable in Japan was the list given in Faye's "Astronomy"; and I am not sure if this is meant to be complete. According to Mr. Aston, the Pèkché comet appeared in May or June, A.D. 302. The nearest date in Faye's list is A.D. 295. If this is the same comet, then one at least of the dates must be wrong. It is quite possible, however, that both are correct; in which case we shall be indebted to Mr. Aston for having added one more to our list of historic comets. In coming to a conclusion, we must know to what source we owe the knowledge of the 295 comet, and whether this source has greater claims to chronological accuracy than have the Korean records. Not having the references at hand for studying these points, I have written this note to NATURE, in the hope that someone interested in the matter may be able to come to a decision on this question of a possibly new historic comet. CARgILl G. KNot't.

Imperial University, Tokio, Japan, December I9, 1887 .

\section{"Is Hail so formed?"}

UNDER the above heading in NATURE of January 26 (p. 295) there is a short paper by Cecil Carus-Wilson, in which the writer assumes that under certain conditions, drops of water, whilst falling from the upper branches of a tree, become converted into ice before reaching the ground, whilst other drops falling from the same tree, but at ro feet less altitude, came to the ground in a fluid state. There is, I think, a simpler solution of this question than the one given. Suppose the following conditions-namely, a frost sufficiently severe as to lower the temperature of the leaves and branches of a tree to a few degrees below the freezingpoint; after which a very gradual thaw comes on, accompanied by a fine rain or Scotch mist which freezes on the tree.

Where the leaves and smaller branches hang downwaràs, small beads of ice would form on their points. As the air became warmer the ice would thaw, and fall to the ground either in the liquid form, or the beads at the ends of the leaves and twigs would become detached in their solid state, and reach the ground as ice-pellets.

Sometimes these ice pellets extend in length, and assume the form? of small icicles.

4 Addison Gardens, January 28.

\section{MODERN VIEWS OF ELECTRICITY.' PART III. (continued).}

VII.

First Representation of the Field due to a Current.

RETURN now to the consideration of a simple circuit, or, say, a linear conductor, and start a current through it ; how are we to picture the rise of the lines of force in the medium ? how shall we represent the spread of magnetic induction? First think of the current as exciting the field (instead of the field as exciting the current, which may be the truer plan ultimately).

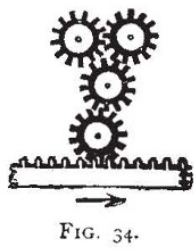

If we can think of electricity in the several molecules of the insulating medium connected like so many cogwheels gearing into one another and also into those of the metal, it is easy to picture a sideways spread of rotation brought about by the current, just as a moving rack will rotate a set of pinions gearing into it and into each other (Fig. 34). But then half the wheels will be rotating one way and half the other way, which is not exactly right.

How is it possible for a set of parallel whirls to be all rotating in the same direction?

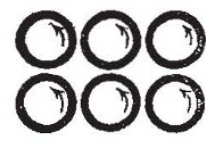

FIG. 35.

If there is any sort of connection between them they will stop each other, because they are moving in opposite directions at their nearest points ; and yet, if there is no connection, how can the whirl spread through the field?

Well, return to the old models by which we endeavoured to explain electrostatics, and think whether they will help us if we proceed to superpose upon them a magnetic whirl in addition to the properties they already

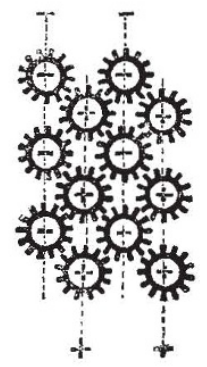

FIG. 36.-Rows of cells alternately positive and negative, geared together; free to turn about fixed axles.

possess. Looking at Figs. 5, 6, and I3, we remember we were led to picture atoms and electricity like beads threaded on a cord. And these cords had to represent, alternately, positive and negative electricity, which always got displaced in different directions.

We are forced to a similar sort of notion in respect of the wheels at present under discussion: in order that 